\title{
A Single Case Study of Dermatomyositis and Management in Ayurveda
}

\author{
D. Ghosh', R. Ghosh ${ }^{2}$ \\ ${ }^{1} \mathrm{MD}$ (AY), PhD (C.U), Superintendent and Ex-officio Professor, Viswanath Ayurved Mahavidyalaya \& \\ Hospital, Kolkata \\ ${ }^{2}$ MBBS (FINAL), GSL Medical College and General Hospital, Rajahmundry, Andhra Pradesh
}

Corresponding Author: D. Ghosh

\begin{abstract}
Background: Dermatomyositis is an idiopathic myopathy involving progressive muscle weakness with skin manifestation. Diagnosis is based upon progressive muscle weakness, skin rashes, increased liver enzymes, high ASO titer. The incidence of dermatomyositis is rare. In this case study, we report a case of classical dermatomyositis without incidence of malignancy.
\end{abstract}

Case Presentation: A 28-year female patient visited the outdoor at Viswanath Ayurved Mahavidyalaya \& Hospital, Kolkata with a fever for two months with scattered rashes all over the body with pain \& swellings and with gradual weight loss.

Conclusion: This case is shifted from allopathy to Ayurveda as in allopathy she did not get any relief. First, this case was treated on the outdoor treatment of ayurvedic hospital then she was shifted to an indoor ward and was under Ayurvedic treatment for about a month. The patient was recovered from her illness and symptoms after the completion of the treatment. Keywords: Dermatomyositis, Ayurveda, Liver enzymes, skin rashes, Uttana vatrakta

\section{INTRODUCTION}

Dermatomyositis (DM) is a skin and muscle inflammatory disorder that lasts for years. Despite the fact that it is classified as an autoimmune disease, the etiopathogenesis is unknown. In DM, skin involvement is characterised by papules over digits, erythema over elbows and knees, a heliotrope rash around the eyes, periungual telangiectasias, and dystrophic cuticles. ${ }^{[10]}$. Muscle involvement usually begins with proximal muscle weakness, which may or may not be accompanied by myalgia or tenderness. An amyopathic variation with minimum to no muscular inflammation has been described. ${ }^{[11]} \mathrm{A}$ connection has been discovered between DM and an increased risk for internal cancer. [10] A little to no muscle inflammatory amyopathic variant was described. ${ }^{[11]}$ A connection between DM and higher internal cancer risk has been established. ${ }^{[12]}$ The occurrence of interstitial lung disease is another key clinical characteristic of DM (ILD). ${ }^{[1-13]}$. This review will go over the clinical characteristics and early detection of DM in adults. First, Bohan and Peter proposed the use of five dermatomyositis diagnostic criteria. These include (1) proximal symmetrical musculoskeletal weakness that progresses over the course of a period of weeks to months; (2) increased serum muscle volume by enzymes derived; (3) an abnormal electromyography, (4) Muscle biopsy abnormalities of degeneration, regeneration, necrosis, phagocytosis, and an interstitial mononuclear infiltrate,(5)Typical skin rash of DM, including a heliotrope rash and Gottron's sign/papules; These criteria are useful to evaluate the patient, but all muscle testing should not be performed in patients with a typical skin disorder, especially those with proximal Muscle Weakness and high muscle-based enzymes.

Dermatomyositis in Ayurveda may be correlated with Uttan Vatarakta with Dhatu gata jwara. Vatarakta is the major 
example of Vata vyadhi, caused due to avarana pathology. The scenario of Utthana Vatarakta occurred owing to the margavarana pathology, which may also be correlated with atherosclerotic peripheral arterial disease. ${ }^{[1-13]}$

\section{PATHOPHYSIOLOGY}

Dermatomyositis has a mainly unknown etiology. The complement system, like many autoimmune illnesses, appears to be the driving force behind endothelial and muscle damage caused by the interaction of genetic susceptibility and the environment. (4). A polymorphism in the tumor necrosis factor promoter and an allele of the HLADQA gene have been identified as risk factors in genetic investigations.(8) Whether these genes or others are to blame, environmental stressors trigger changes that set the scene for the disease after a genetic foundation has been established. Medications (hydroxyurea, phenytoin, nonsteroidal anti-inflammatory drugs, and statins), viruses (human immunodeficiency virus, Escherichia coli, and Coxsackie virus), malignancy, and UV radiation are some of the recognized environmental triggers. Autoreactivity (reaction against our cells) arises in response to genetic and environmental cues. Complement pathways generate enzymes, activate immune complexes, and eventually generate membrane assault complexes. The most critical component for this powerful system is regulated by the complement system which can lyse cells, clear debris, activate cytokines, and launch inflammatory mediators. Autoantibody proliferation is caused by complement insufficiency, whereas tissue injury is caused by complement overactivation. When complement defences fail, as in dermatomyositis, the body's cells attack, which is not ordinarily antigenic. The formation of autoantibodies begins. Complement system components and membrane assault complex cells can be discovered in patients early in the disease phase, as expected. These components cause cell death in endothelial cells. Interface dermatitis is a disorder that begins at the dermo-epidermal junction and manifests itself in histologic samples. Basal cell vacuolization (spaces and cavities between basal cells and dermis), apoptotic keratinocytes (dead keratinocytes and their debris), and inflammatory infiltration are all common observations. Cytokines, such as type 1 and 2 interferons, are produced in excess. Interferons are involved in most autoimmune illnesses and chronic inflammation, and in dermatomyositis, they can harm both endothelial cells and myofibers. The complement system is also involved in inflammation, which destroys capillaries and results in ischemic muscle injury. Autoantibodies specific to myositis have been detected in $50 \%$ to $70 \%$ of patients with dermatomyositis. Dermatomyositis patients frequently have abnormal muscle enzyme levels, resulting in muscle weakness, impairment, and contractures. Sixty percent of patients seek treatment when both muscle and skin symptoms become bothersome, while thirty percent of patients only have a skin rash.

This indicates that 90 percent of patients with dermatomyositis will exhibit the classic cutaneous characteristics when they first show. Even when muscle weakness is reduced, dermatomyositis rash generates significant itching and burning, which can be recalcitrant to treatment. Patients with dermatomyositis had significantly lower quality of life, energy levels, depression, and mood scores than patients with comparable inflammatory skin diseases and patients with chronic health conditions such as hypertension, recent myocardial infarction, or diabetes, according to a recent study. Patients who complain of muscle weakness say it's growing harder to get out of a chair, comb their hair, or walk the stairs. Fortunately, this skin rash can be highly distinct, providing critical diagnostic signals that allow for early detection and screening. ${ }^{[1-13]}$ In Uttana Vatrakta, the disease pathology affects the superficial tissues like skin and muscles, the clinical features are limited in 
the skin and muscles, look like a skin lesion or muscular pain

\section{CASE REPORT}

A 28-year-old female patient visited the outdoor clinic of this hospital on 19.8.15. Her chief complaint at the time of visit was a fever for two months with rashes scattered all over the body with pain and swelling over the muscles of lower and upper extremities with violet heliotrope rashes on the upper eyelids and she was complaining of gradual weight loss.

\section{History and Treatment}

The patient was diagnosed with Dermatomyositis at Christian Medical College, Vellore. She had taken Tab Mycept S 360mg, Nicardia Retard 10, Metacin, Methotrexate, Tab Prednisolone, etc. but no significant result was found after two years of that treatment. Then she had come to this Hospital at O.P.D. and was advised to take Ayurvedic medicines for 1 month. And finally, she had advised admission to this hospital on 12.09.15

\section{Family history}

Nothing significant. No evidence of the type of disease in the family

\section{Physical examination}

The patient had Anaemia but Icterus, Cyanosis, Clubbing are not present in this case. The patient had edema in the lower extremities. On cardiovascular system examination, S1 (first heart sound) \& S2 (second heart sound) were audible. The chest of the patient was bilaterally clear. Body Temperature of the patient was $102^{\circ}$ F, Blood pressure of the patient was 100/60 mm of Hg, Pulse: 90 beats/min.

\section{Investigation}

Blood investigation was done: $\mathrm{CBC}$, Ur, Cr, U.A., FBS, PPBS, HbA1C, Lipid Profile, LFT, CRP, RA Factor, ASO Titre, ANA, Myositis Profile report.

All were normal except - (Table 1)

USG Abdomen showed the presence of Grade 1 steatohepatitis, cholelithiasis.
Table 1

\begin{tabular}{|l|l|l|}
\hline TEST & FINDINGS & $\begin{array}{l}\text { REFERENCE } \\
\text { RANGE }\end{array}$ \\
\hline CRP (C-reactive protein) & 60 & $\begin{array}{l}\text { Less than } \\
10 \mathrm{mg} / \mathrm{lit}\end{array}$ \\
\hline $\begin{array}{l}\text { ASO Antistreptolysin O) } \\
\text { Titre }\end{array}$ & 290 & $\begin{array}{l}\text { Less than } \\
200 \mathrm{IU} / \mathrm{ml}\end{array}$ \\
\hline Hb\% & 7.5 & $\begin{array}{l}13.5-17.5 \% \\
\text { (women) }\end{array}$ \\
\hline $\begin{array}{l}\text { ESR(Erythrocyte sedimentation } \\
\text { rate) }\end{array}$ & 107 & $\begin{array}{l}\text { Less than } \\
20 \mathrm{~mm} / \mathrm{hr} \\
\text { (for women age } \\
\text { between 0-50) }\end{array}$ \\
\hline $\begin{array}{l}\text { SGPT(Serumglutamic-pyruvic } \\
\text { transaminase or ALT) }\end{array}$ & 167 & $\begin{array}{l}5 \text { to 40 units } \\
\text { per liter of } \\
\text { serum }\end{array}$ \\
\hline $\begin{array}{l}\text { SGOT(serum glutamicoxalo } \\
\text { acetic or AST) }\end{array}$ & 189 & $\begin{array}{l}7 \text { to } 56 \text { units } \\
\text { per liter of } \\
\text { serum. }\end{array}$ \\
\hline $\begin{array}{l}\text { ANA (AntiNuclear Antibody) } \\
\text { weakly positive, Myositis } \\
\text { Profile report }\end{array}$ & weakly \\
\hline
\end{tabular}

8. Previously taken treatment:

1. Tab Defcort $18 \mathrm{mg}$ TDC for 1 month

2. Tab methotrexate $15 \mathrm{mg}$ once a week for 3 months

3. Tab folic acid $5 \mathrm{mg}$ twice a week for 3 months

4. Tab Pantoprazole 40mg OD

5. Calcirol 60000 IU GRANULES 1 sachet once a week.

6. Tab osteocalm BD

After the above medication, there was no relief at all. Then the patient was shifted to ayurvedic treatment.

\section{Ayurvedic therapeutics managements:}

Table 2

\begin{tabular}{|c|c|c|}
\hline Date & medicine & dose \\
\hline \multirow[t]{7}{*}{12.9 .2015} & $\begin{array}{l}\text { Powder Virechan with Eranda } \\
\text { taila }\end{array}$ & 1 T.S.F at H.S. \\
\hline & $\begin{array}{l}\text { Powder Chatusama 1TSF with } \\
\text { Powder VajraKshar 500mg }\end{array}$ & $\begin{array}{l}\text { 1dose BDPC for } \\
7 \text { days }\end{array}$ \\
\hline & Syp. Dasamool Kwath & $\begin{array}{l}\text { 3TSF BDPC } \\
\text { with water }\end{array}$ \\
\hline & Tab Carsona & $\begin{array}{l}1 \text { tab BDPC with } \\
\text { a cup of milk }\end{array}$ \\
\hline & Tab Jaymangal ras & 1 tab ODPC \\
\hline & Tab Kaisore guggul & 2 tab ODPC \\
\hline & Wheatgrass juice & $\begin{array}{l}\text { 10ml in an empty } \\
\text { stomach }\end{array}$ \\
\hline \multirow[t]{2}{*}{16.9 .15} & Godhanarka & $\begin{array}{lr}1 \quad \text { TSF } & \text { after } \\
\text { breakfast } & \text { and } \\
\text { tiffin } & \\
\end{array}$ \\
\hline & Other medicines are continued & \\
\hline \multirow{2}{*}{$\begin{array}{l}15.10 .15 \\
\text { (patient } \\
\text { was } \\
\text { discharged } \\
\text { with } \\
\text { follow-up } \\
\text { medicines) }\end{array}$} & Vidanga churna & $\begin{array}{l}1 \mathrm{TSF} \text { at HS with } \\
\text { L.W.W. }\end{array}$ \\
\hline & $\begin{array}{l}\text { Mahasudarshan } 1 \text { Tab BDPC } \\
\text { Chywanprash } 1 \text { tsf BDPC } \\
\text { Wheat Grass Juice } 10 \mathrm{ml} \\
\text { ODAC } \\
\text { Godhanarka } 1 \text { TSF ODPC at } \\
\text { 6:00 PM }\end{array}$ & \\
\hline
\end{tabular}


The patient was administered with ayurvedic classical medicines and proprietary medicines mentioned in table 1 . On 16.9.15 another medicine was added to the existing medicines. Pain relieved and swelling subsided than before, rashes gradually disappearing and fever also remitted. The patient was discharged on 15.10.2015 with the final diagnosis of Uttan Vatarakta with Dhatu gata jwara.

\section{Pathya-Apathya:}

Apathya: Chana (Cicer sp.), matar (Lathyrus sp.), badam (Arachis sp), curd, Musa paradisiaca, eggs, ladies finger, Urad dal (Vigna sp.)

\section{RESULTS}

The Pain relieved and swelling subsided than before, rashes gradually disappearing and fever also remitted.

\section{DISCUSSION}

Dermatomyositis may be correlated with Uttan Vatarakta with dhatugata jwara in Ayurveda. In dermatomyositis, muscles and skin are affected and in Uttan vatrakta, also, muscles and skin are involved. Rashes are described to be found in dermatomyositis and vatrakta in Ayurveda. As in vatrakta, snigdha virechan is indicated. The patient was advised to take Eranda taila with Virechan powder. Tab Jaymangal Ras was given for treating Dhatugata Jwara. Tab Kaishore Guggul is one of the best drugs for Vatarakta, so it was advised to this patient. To enhance her $\mathrm{Hb} \%$ and control her infection, wheatgrass juice and Godhan arka were advised respectively

This patient was taken treatment of modern medicine but not cured. Then this patient came under Ayurvedic treatment. After one month of treatment, she was recovered from all signs and symptoms of dermatomyositis, now she is clinically fit. This case will help the researcher for further study. This single case study is also significant to the clinician for a further clinical trial on this disease which helps to prepare an ideal treatment protocol for dermatomyositis in Ayurveda. On discharge, the patient was advised to take chywanprash and tab Mahasudarshan for immunomodulatory action and prevention for onset of fever respectively.

\section{CONCLUSION}

Dermatomyositis (DM) is an autoimmune chronic disease characterized by distinctive skin lesions with muscular pain and inflammation which can be correlated with the Uttan vatarakta of Ayurveda. In this study, the result shows that the Ayurveda has a definite role to treat the patient of Dermatomyositis with the line up treatment of Uttan vatrakta and Dhatugata Jwara chikitsa in Ayurveda. The case report reveals that the treatment failure patient of the conventional system of treatment comes to Ayurveda with a hope of recovery even from a critical disease. So the present situation demands more clinical research and studies in Ayurveda to develop the standard treatment protocols for incurable disease in the conventional system of medicine. ${ }^{[1-13]}$

\section{Patients Declaration:}

The authors certify that they have obtained all appropriate patient consent forms. In the form, the patient has given her consent for her images and other clinical information to be reported in the journal. The patient understands that her name and initials will not be published and due efforts will be made to conceal her identity, but anonymity cannot be guaranteed.

\section{Financial Support and Sponsorship: Nil.}

\section{Conflicts of interest:}

There are no conflicts of interest.

\section{Code availability}

Not applicable

\section{Authors' contributions}

Conceptualization: [Debasish Ghosh], [Rajdeep Ghosh]; Methodology: [Debasish Ghosh], [Rajdeep Ghosh]; Formal analysis and investigation: [Debasish Ghosh], [Rajdeep Ghosh]; Writing-original draft preparation: [Rajdeep Ghosh], [Debasish 
Ghosh]; Writing-review and editing: [Debasish Ghosh]; Funding acquisition: [N/A]; Resources: [N/A]; Supervision: [Debasish Ghosh]

\section{Consent to participate}

All the authors mutually agree to participate in this work.

\section{Consent for publication}

All the authors mutually agree to submit the manuscript for publication.

\section{ACKNOWLEDGEMENTS}

We don't have any funding support from any organizational or institutional level.

\section{REFERENCES}

1. Dermatomyositis Part 2: Diagnosis and Treatment Reid Waldman, M.D., Madeline E. DeWane, B.A., Jun Lu, M.D. Journal of the American Academy of Dermatology S0190-9622(19)32308-4

2. Dermatomyositis Part I: Clinical Features and Pathogenesis Madeline E. De Wane, B.A., Reid Waldman, M.D., Jun Lu, M.D. Journal of the American Academy of Dermatology S0190-9622(19)32309-6

3. Davidson, Principle, and practice of medicine, edited by Haslett Chilvers Edwin R. et al. Nineteenth Edition, 2002, 866.

4. Pandit Kashinaath Shastri, Dr. Gorakhnath Chaturvedi Charak Samhita of Maharshi Charak, Chukambhaprakashan, Varanasi, siddhi sthana, chapter 1, page no.971

5. Pandit Kashinaath Shastri, Dr. Gorakhnath Chaturvedi Charak Samhita of Maharshi
Charak, Chukambhaprakashan, Varanasi, siddhi sthana, chapter 4, page no.1013

6. Prof. Sidhdhi Nandan Mishra, Bhaishajya Ratnavali, Chukambha Surbharati Prakashan, Varanasi, chapter 5, page no. 105

7. Prof. Sidhdhi Nandan Mishra, Bhaishajya Ratnavali, ChukambhaSurbharatiPrakashan, Varanasi, chapter 71, page no. 1088

8. Prof. Sidhdhi Nandan Mishra, Bhaishajya Ratnavali, ChukambhaSurbharatiPrakashan, Varanasi, chapter 26, page no. 528

9. Prof. Sidhdhi Nandan Mishra, Bhaishajya Ratnavali, ChukambhaSurbharatiPrakashan, Varanasi, chapter 71, page no. 1093

10. Callen JP, Wortmann RL. Dermatomyositis. Clin Dermatol. 2006; 24:363-73.

11. Sontheimer RD. Would a new name hasten the acceptance of amyopathic dermatomyositis (dermatomyositis sine myositis) as a distinctive subset within the idiopathic inflammatory dermatomyopathies spectrum of clinical illness? J Am Acad Dermatol. 2002;46:626-36.

12. Madan V, Chinoy H, Griffiths CE, Cooper RG. Defining cancer risk in dermatomyositis. Part I. Clin Exp Dermatol. 2009;34:451-5

13. Clinical Presentation and Evaluation of Dermatomyositis Umaima Marvi, Lorinda Chung and David F Fiorentino, Indian J Dermatology 2012 Sep-Oct; 57(5): 375381.

How to cite this article: D. Ghosh, R. Ghosh. A single case study of dermatomyositis and management in ayurveda. Gal Int J Health Sci Res. 2021; 6(2): 64-68. DOI: https://doi.org/ 10.52403/gijhsr.20210409 